Our Nature (2005)3:77-80

\title{
Some Fresh Water Algae of Eastern Uttar Pradesh, India
}

\author{
P.K. Misra, A.K. Srivastava, J. Prakash ${ }^{1}$, D.K. Asthana ${ }^{1}$ and S.K. Rai ${ }^{2}$ \\ Department of Botany, Lucknow University, Lucknow-226007, U.P., India \\ ${ }^{1}$ Department of Botany, D.A.V. College, Kanpur, U.P., India \\ ${ }^{2}$ Department of Botany, P.G. Campus, Tribhuvan University, Biratnagar, Nepal \\ Email: shivarai2003@yahoo.com
}

\begin{abstract}
Present communication deals morpho-taxonomic description of 11 fresh water algae belonging to class Chlorophyceae and Bacillariophyceae. Chlorophycean genera are Pediastrum Meyen (1 sp), Cladophora (2 spp), Staurastrum (3 spp), Onychonema (2 spp) and Desmidium (1 sp) while Bacillariophycean genera are Navicula (1 sp) and Rhopalodia (1 $\mathrm{sp)}$.

Key words: Bacillariophyceae, Chlorophyceae, Eastern Uttar Pradesh, Fresh water algae
\end{abstract}

\section{Introduction}

In the present communication 11 fresh water algal species of Talkunda pond have been morpho-taxonomically described. Talkunda pond is situated in Siddartha Nagar district of eastern Uttar Pradesh, India. District Siddartha Nagar is surrounded by Nepal (north), Maharaj ganj (east), Basti/Sant Kabir Nagar (south) and Balrampur (west). Earlier, Misra et al. (2002, 2002a-c, 2003, 2004, 2005) have reported a large number of algae from this region of Uttar Pradesh.

\section{Materials and Methods}

Algal samples were collected with the help of Planktonic mesh net in one liter polythene bottles and preserved in $4 \%$ formalin. Chlorophycean algae were stained with iodine and mounted in glycerine. Bacillariophycean taxa were studied after clearing the frustule by concentrated sulphuric acid and potassium dichromate method of Patrick and Reimer (1966). Detailed studies were made under Nikon Labophot microscope E-II with camera attachment.

\section{Morpho-Taxonomic Description}

Class: Chlorophyceae

Order: Chlorococcales

Family: Hydrodictyaceae

Genus: Pediastrum Meyen 1829

1. Pediastrum duplex Meyen (Fig. 3)

Philipose, M.T. 1967, P. 121, Fig. 43b

Colonies $160 \mathrm{~m}$ in diameter with 16-64 cells; cell $18 \mathrm{~m}$ in diameter with small lens shaped perforations between cells, inner cells quadrate to angular, inner side of marginal cell concave, outside produced in to short truncate process.

Order: Cladophorales

Family: Cladophoraceae

Genus: Cladophora Kuetzing 1843

2. Cladophora glomerata (L) Kuetz. var. glomerata dh Den Hoek (Fig. 2)

Prasad, B.N. and P.K. Misra 1992, P. 53-54, Pl. 7, Figs. 1-2

Fronds attached; branches of main axis organized in acropetal fashion; cells of main branch 210-215 m long, 36-38 m broad; 
P.K. Misra, A.K. Srivastava, J. Prakash, D.K. Asthana and S.K. Rai / Our Nature (200)3:71-74

cells of branchlet $145 \mathrm{~m}$ long, $30 \mathrm{~m}$ broad. reniform, lateral apex acute with spine.

3. Cladophora oligoclona Kuetz. (Fig. 1) Prescott, G.W. 1951, P. 139, Pl. 21, Figs. 6-8

Attached on snail shell as epizoic; thallus branched; cells of main axis 235-240 m long, 36-38 m broad, cylindrical; cells of branchlet $156 \mathrm{~m}$ long, 31-34 $\mathrm{m}$ broad.

Order: Zygnemales

Family: Desmidiaceae

Genus: Staurastrum Meyen 1829

4. Staurastrum leave Ralfs (Fig. 4)

Flint, E.A. and D.B. Williamson 1999, P. 548 , Fig. $4 d$

Cells slightly longer than broad; cells 27.5

$\mathrm{m}$ long, $25.4 \mathrm{~m}$ broad (with process);

isthmus $7.3 \mathrm{~m}$

5. Staurastrum sexangulare Lund. var. productum Nordst. (Fig. 5)

Flint, E.A. and D.B. Williamson 1999, P. 550, Fig. $4 \mathrm{~h}$

Cells longer than broad with radiate process, median constriction deep in top view; cells $31.4 \mathrm{~m}$ long, $30 \mathrm{~m}$ broad (with process); isthmus $12 \mathrm{~m}$.

6. Staurastrum sp. (Fig. 6)

Cells 30-32 m long, $34.5 \mathrm{~m}$ broad (with process); isthmus $9.3 \mathrm{~m}$

Genus: Onychonema Wallich 1860

7. Onychonema leave Nordst. var. latum West et West (Fig. 9)

Scott, A.M. and G.W. Prescott 1961, P. 121, Pl. 60, Fig. 13

Cells wider than long, compressed, deeply constricted, united into filament without a gelatinous sheath; cells $16 \mathrm{~m}$ long, $28 \mathrm{~m}$ broad; semicells broadly elliptical or sub-
8. Onychonema sp. (Fig. 8)

Cells wider than long, compressed, deeply constricted, united into filament; cells $60 \mathrm{~m}$ long, $80 \mathrm{~m}$ broad; semicells elliptic or tubular, lateral apex broad and rounded without spine.

Genus: Desmidum Aragdh 1824

\section{Desmidium sp. (Fig. 7)}

Cells united to form straight filament, gelatinous sheath present, median constriction reduced to a faint undulation, cell outline rectangular; cells 18-19 m long, 25$26 \mathrm{~m}$ broad.

Remark: The present specimen is morphologically similar with $D$. swartzii (Ag.) Ag. ex Ralfs, but due to the presence of distict filamentous sheath, this taxa is openly described.

Class: Bacillariophyceae

Order: Bacillariales

Family: Naviculaceae

Genus: Navicula (Bory 1822) Cleve 1894

10. Navicula cuspidate Kuetz. var. ambigua (Ehr.) Cl. (Fig. 11)

Prasad, B.N. and M.N. Srivastava 1992, P. 207-208, Pl. 28, Fig. 3

Ave long, $75 \mathrm{~m}$ long, $22 \mathrm{~m}$ broad, broadly lanceolate with narrowly constricted much produced flately rostrate capitate ends;

striae 16 in $10 \mathrm{~m}$, fine.

Family: Epithemiaceae

Genus: Rhopalodia Mueller 1895

11. Rhopalodia gibba (Kuetz.) Muell. (Fig. 10)

Tiffany, L.H. and M.E. Britton 1995, P. 282, 
P.K. Misra, A.K. Srivastava, J. Prakash, D.K. Asthana and S.K. Rai / Our Nature (200)3:71-74

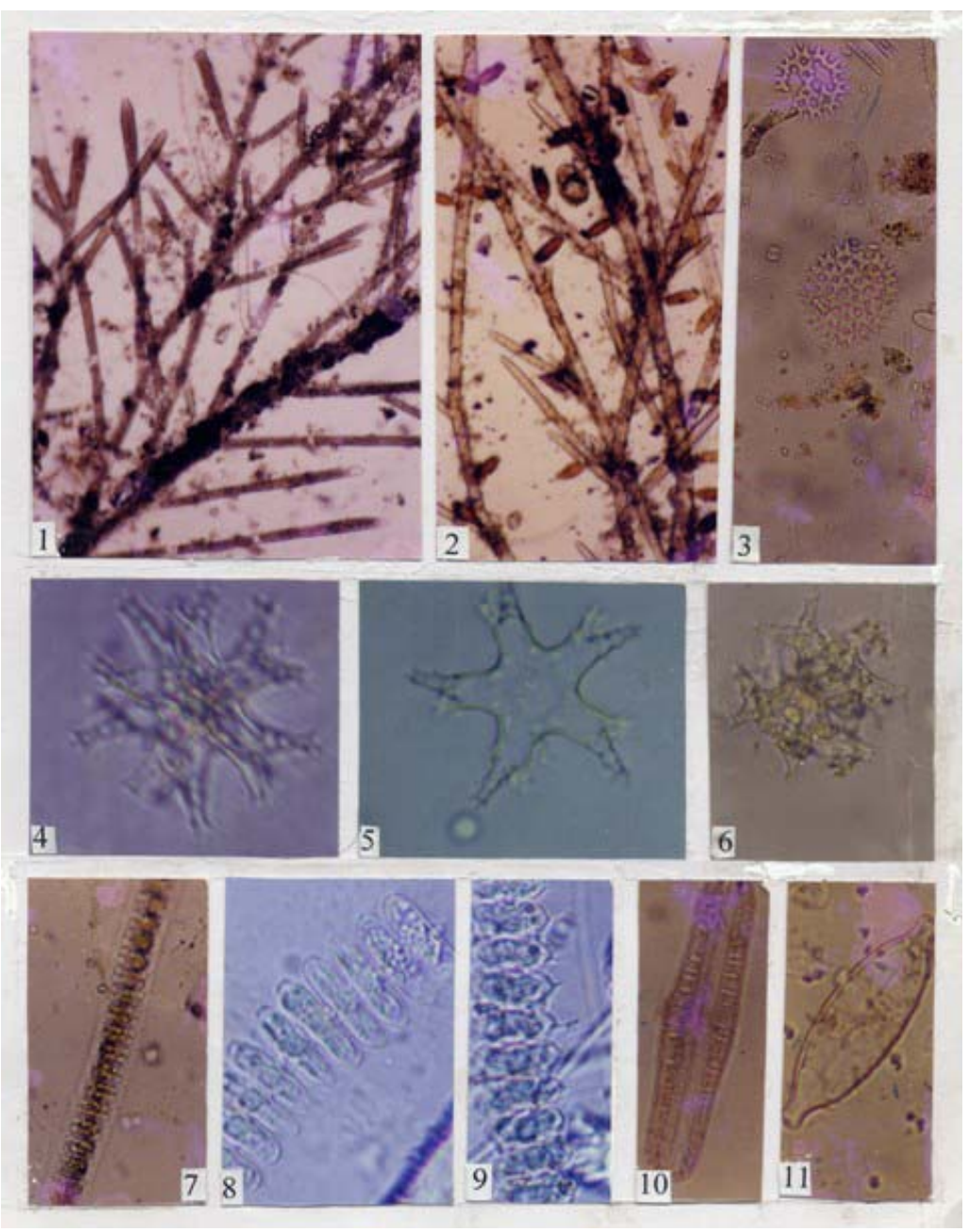

Figures: 1. Cladophora oligoclona Kuetz. (*50) 2. Cladophora glomerata (L) Kuetz. var. glomerata dh Den Hoek (*50) 3. Pediastrum duplex Meyen (800) 4. Staurastrum leave Ralfs (800) 5. Staurastrum sexangulare Lund. var. productum Nordst. (800) 6. Staurastrum sp. (*50) 7. Desmidium sp. (800) 8. Onychonema sp. (850) 9. Onychonema leave Nordst. var. latum West et West (850) 10. Rhopalodia gibba (Kuetz.) Muell. (800) 11. Navicula cuspidate Kuetz. var. ambigua (Ehr.) Cl. (800) 
P.K. Misra, A.K. Srivastava, J. Prakash, D.K. Asthana and S.K. Rai / Our Nature (200)3:71-74

P1. 75 , Fig. 884

Cells in girdle view broadly linear, $60 \mathrm{~m}$ long, $28 \mathrm{~m}$ broad, elliptic clavate, medianly inflated with broadly rounded poles; costae 6 in $10 \mathrm{~m}$.

\section{Results and Discussion}

A total number of 11 fresh water algal taxa including 7 genera, 8 species and 4 varieties belonging to families Hydrodictyaceae, Cladophoraceae, Desmidiaceae of Class Chlorophyceae and families Naviculaceae and Epithemiaceae of class Bacillariophyceae have for the first time morpho-taxonomically described from the area. Three specimens are described under open nomenclature system as specific characters do not resemble with the known species of the genus. They were actually rare in collection. Specific names are designated after culturing the specimen.

\section{Acknowledgement}

The authors are thankful to the Head, Department of Botany, Lucknow University, Lucknow for laboratory facilities.

\section{References}

Flint, E.A. and D.B. Williamson 1999. Desmids (Chlorophyta) in small tarn in Central Cantenbury, New Zealand. New Zealand J. Bot. 37: 541-551.

Misra, P.K., A.K. Srivastava and J. Prakash 2002. Morpho-taxonomic survey on Ulotrichales and Cladophorales of North-Eastern Uttar Pradesh, India. J. Ind. bot. Soc. 81(3-4): 345-350.
Misra, P.K., A.K. Srivastava, J. Prakash and S.K. Rai 2005. Some fresh water filamentous chlorophycean algae from district Balrampur, Uttar Pradesh, India. Eco. Env. \& Cons. 11(3-4): 429-431.

Misra, P.K., J. Prakash and A.K. Srivastava 2002a Filamentous green algae from district Basti, U.P. Phytotaxonomy 2(1): 130-134.

Misra, P.K., J. Prakash and A.K. Srivastava 2002b. Fresh water green algae from district Basti, U.P. Geophytology 31(1-2): 103-109.

Misra, P.K., J. Prakash, A.K. Srivastava and P.K. Singh 2004. Some fresh water planktonic algae from Sant Kabir Nagar, U.P. Phytotaxonomy 4: 87-94.

Misra, P.K., R.K. Mehrotra, J. Prakash and A.K. Srivastava 2003. Fresh water green algae from Basti district, U.P. Geophytology 31(1-2): 1-7.

Misra, P.K., R.K. Mehrotra, J. Prakash, A.K. Srivastava and S. Kishore 2002c. Fresh water planktonic algae from district Basti, U.P. Geophytology 30(12): $61-73$

Patrick, R. and C.W. Reimer 1966. The diatoms of the United States, exclusive of Alaska and Hawaii. Monograph of the Academy of Natural Sciences, Philadelphia, No. 13, dI. I. $688 \mathrm{p}$.

Philipose, M.T. 1967. Chlorococcales, I.C.A.R. monograph on algae, New Delhi. 365p.

Prasad, B.N. and M.N. Srivastava 1992. Fresh water algal flora of Andaman and Nicobar Islands, Vol. I. B. Singh and M.P. Singh, Dehradun, India. 369 p.

Prasad, B.N. and P.K. Misra 1992. Fresh water algal flora of Andaman and Nicobar Islands, Vol. II. B. Singh and M.P. Singh, Dehradun, India. 284 p.

Prescott, G.W. 1951. Algae of the Western great lakes area. WM.C. Brown Publishers, Dubuque, Iowa. 977p.

Scott, A.M. and G.W. Prescott 1961. Indonesian desmids. Hydrobiol. 17(1-2): 1-132. 